ARTICLE

https://doi.org/10.1038/s41467-019-09401-9

\title{
IL-4 together with IL-1 $\beta$ induces antitumor Th9 cell differentiation in the absence of TGF- $\beta$ signaling
}

\author{
Gang Xue ${ }^{1}$, Guangxu Jin², Jing Fang ${ }^{1} \&$ Yong $\mathrm{Lu}^{1}$
}

IL-9-producing $\mathrm{CD}^{+}$(Th9) cells are a subset of $\mathrm{CD} 4^{+} \mathrm{T}$-helper cells that are endowed with powerful antitumor capacity. Both IL-4 and TGF- $\beta$ have been reported to be indispensable for Th9 cell-priming and differentiation. Here we show, by contrast, that Th9 cell development can occur in the absence of TGF- $\beta$ signaling. When TGF- $\beta$ was replaced by IL-1 $\beta$, the


Th9 $9^{\mathrm{L}-4+} \mathrm{IL}-1 \beta$ cells are phenotypically distinct $T$ cells compared to classic Th9 cells (Th9lL-4+TGF- $\beta$ ) and other Th cells, and are enriched for IL-1 and NF- $\mathrm{kB}$ gene signatures. Inhibition of NF-KB but not TGF- $\beta$-signaling negates IL-9 production by Th9lL-4+IL-1 $\beta$ cells. Furthermore, when compared with classic Th9lL-4+TGF- $\beta$ cells, Th9lL-4+IL-1 $\beta$ cells are less exhausted, exhibit cytotoxic $T$ effector gene signature and tumor killing function, and exert a superior antitumor response in a mouse melanoma model. Our study thus describes an alternative pathway for Th9 cell differentiation and provides a potential avenue for antitumor therapies.

\footnotetext{
${ }^{1}$ Department of Microbiology \& Immunology, Wake Forest School of Medicine, Winston-Salem, NC, USA. ${ }^{2}$ Department of Cancer Biology, Wake Forest School of Medicine, Winston-Salem, NC, USA. Correspondence and requests for materials should be addressed to Y.L. (email: yolu@wakehealth.edu)
} 
nterleukin-9 (IL-9)-producing CD4 ${ }^{+}$T helper 9 (Th9) cells are a distinct subset of Th cells induced from naive $\mathrm{CD} 4^{+} \mathrm{T}$ cells by IL- 4 together with transforming growth factor- $\beta$ (TGF- $\beta$ ) cytokine signaling ${ }^{1,2}$. Although Th9 cell differentiation requires a regulatory network of transcription factors and Th9 cells express transcription regulators such as PU.1, IRF4, STAT6, GATA3, BATF, STAT5, HIF1 $\alpha$, and Foxo ${ }^{3-10}$, a unifying master transcription factor is still ambiguous. In addition to roles in allergic inflammation and autoimmune diseases, the most intriguing function of Th9 cells is their antitumor activity ${ }^{4,10-12}$. We were among the first to report antitumor features of Th9 cells ${ }^{13}$. Furthermore, increased physiological Th9 cell counts during nivolumab (anti-PD-1 antibodies (Abs)) treatment were associated with an improved clinical response among patients with metastatic melanoma ${ }^{14}$. More recently, we reported that Th9 cells represent a novel third paradigm for T cell therapythey are less exhausted, fully cytolytic, and hyperproliferative, and only tumor-specific Th9 cells completely eradicated late-stage advanced tumors, a scenario more like that seen clinically ${ }^{15}$. Thus further work to elucidate the development of Th9 cells is warranted.

Signals from IL- 4 and TGF- $\beta$ have been recognized as indispensable for Th9 cell differentiation, and neither IL- 4 nor TGF- $\beta$ is sufficient by itself to generate the Th9 cell transcriptional profile or to induce high amounts of IL-9 expression in $\mathrm{T}$ cells ${ }^{6,10,16}$. One study showed that Activin A, a member of TGF- $\beta$ superfamily, may replicate the function of TGF- $\beta$ in driving in vitro generation of Th9 cells ${ }^{17}$. However, the requirement for TGF- $\beta$ signaling is unclear; one report has shown that IL-9 production from CD $4^{+} \mathrm{T}$ cells during a parasite infection is comparable between wild-type (WT) mice and TGF- $\beta$ RII dominant-negative mice (which express a dominant-negative TGF- $\beta$ receptor) ${ }^{18}$. Thus in the current study we sought to identify the potential of other cytokine combinations that may lead to Th9 cell priming and development.

Here we report that Th9 cell differentiation can occur in the absence of TGF- $\beta$ signaling. IL- 4 in combination with IL- $1 \beta$ effectively induces generation of IL-9-producing $\mathrm{CD}^{+} \mathrm{T}$ cells (Th9 $9^{\mathrm{IL}-4+\mathrm{IL}-1 \beta}$ ), independent of endogenous TGF- $\beta$ signaling. We demonstrate that the nuclear factor $(\mathrm{NF})-\kappa \mathrm{B}$ pathway is required for IL-9 production in Th $9^{\mathrm{IL}-4+\mathrm{IL}-1 \beta}$ cells. Furthermore, Th9 $9^{\mathrm{IL}-4+\mathrm{IL}-1 \beta}$ cells promote antitumor immune responses in our experimental tumor-bearing model in vivo, achieving superior outcomes than those from classic Th9IL-4+TGF- $\beta$ cells.

\section{Results}

IL-4 together with IL-1 $\beta$ induces IL-9-producing CD4 ${ }^{+}$Th9 cells. Classic Th9 cells are induced by IL- 4 in combination with TGF- $\beta$ cytokine signaling. Here we investigated whether TGF- $\beta$ or IL-4 may be replaced by other cytokines to generate IL-9-producing $\mathrm{CD}^{+} \mathrm{T}$ cells. First, we primed naive tyrosinase-related protein (TRP)-1-specific $\mathrm{CD}^{+}{ }^{+} \mathrm{T}$ cells with TRP-1 peptide-loaded antigenpresenting cells (APCs) by IL-4 in combination with other cytokines; we also generated other Th cell subsets Th1, Th2, Th17, and Th2 2 and classic Th9 ${ }^{\mathrm{IL}-4+\mathrm{TGF}-} \beta$ cells as controls. IL- 4 plus IL-1 $\beta$, but not other cytokines, induced a significant amount of Il9 expression comparable to classic Th9IL-4+TGF- $\beta$ cells generated under conventional IL- 4 and TGF- $\beta$ conditions (Fig. 1a). We also primed naive TRP-1-specific CD4 ${ }^{+}$T cells by TGF- $\beta$ in combination with other cytokines. However, only TGF- $\beta$ incorporated with IL-4 to promote Il9 gene expression, and no other cytokine appeared to replace the role of IL-4 (Supplementary Figure 1). These results suggest that the new cytokine milieu (IL-4+IL-1 $\beta$ ) plays a crucial role and effectively induces IL-9-producing CD4 ${ }^{+}$ cells. We further confirm that IL-4, IL-1 $\beta$, or TGF- $\beta$ is not sufficient to upregulate IL-9 expression at both the gene (reverse transcriptase-PCR (RT-PCR)) and protein (enzyme-linked immunosorbent assay (ELISA)) levels, whereas IL-4+IL-1 $\beta$ induces IL-9 expression comparable to the classic IL-4+TGF- $\beta$ cocktail (Fig. 1b, c). The concentration of IL-1 $\beta$ at $10 \mathrm{ng} / \mathrm{ml}$ was used thereafter because it is the optimal dose for IL-9 expression in Th9 $9^{\mathrm{IL}-4+\mathrm{IL}-1 \beta}$ cells (Supplementary Figure 2). In addition, Th9 ${ }^{\text {IL- } 4+\mathrm{IL}-1 \beta}$ and Th9 $9^{\mathrm{IL}-4+\mathrm{TGF}-\beta}$ cells also produce a similar level of IL-10, which has been considered as another cytokine associated with Th9 cells (Supplementary Figure 3). The intracellular staining further supported the IL-9 production in Th9 $9^{\mathrm{IL}-4+\mathrm{IL}-1 \beta}$ cells (Fig. 1d, e), whereas Th9 $9^{\mathrm{IL}-4+\mathrm{IL}-1 \beta}$ or Th9 $9^{\mathrm{IL}-4+\mathrm{TGF}-} \beta$ cells produced limited IL-4, IL-5, or IL-13 (Supplementary Figure 4). Taken together, IL- 4 with IL- $1 \beta$ is an alternative cytokine combination that efficiently induces IL-9-producing $\mathrm{CD}^{+}{ }^{+}$cells.

The generation of Th9 $9^{\mathrm{IL}-4+\mathrm{IL}-1 \beta}$ cells is not limited to TRP-1specific $\mathrm{CD}^{+} \mathrm{T}$ cells. We also used ovalbumin (OVA)-specific $\mathrm{CD}^{+}{ }^{+} \mathrm{T}$ cells (from OT-II mice) and generated a similar IL-9producing Th9 ${ }^{\mathrm{IL}-4+\mathrm{IL}-1 \beta}$ cells (Supplementary Figure 5). To determine in which cells, T cells and/or APCs, IL- $1 \beta$ signaling is required, we cocultured WT $\mathrm{T}$ cells and Illr-deficient APCs or Illr-deficient T cells and WT APCs. As shown in Supplementary Figure 6a, b, Illr deficiency in T cells but not APCs abrogated IL-9 production of Th $9^{\mathrm{IL}-4+\mathrm{IL}-1 \beta}$ cells. In addition, IL- $4+\mathrm{IL}-1 \beta$ is sufficient to induce IL-9 expression in naive $\mathrm{CD}^{+} \mathrm{T}$ cells stimulated with plate-bound aCD3/aCD28 mAbs (Supplementary Figure $6 c$, d). Finally, in mice bearing lung metastatic B16-OVA tumors, Illr deficiency or $\mathrm{CD}^{+} \mathrm{T}$ cell-depletion significantly impaired the IL-9 production of leukocytes isolated from the lung tumor tissues (Supplementary Figure 7), suggesting that IL-1 $\beta$ also contributes to the generation of IL-9-secreting $\mathrm{T}$ cells in vivo.

Th9 ${ }^{\text {IL-4+IL-1 } \beta}$ cells display a distinct gene signature. Next, we explored whether IL-4- and IL- $1 \beta$-induced Th9IL-4+ IL-1 $\beta$ cells represent a unique $\mathrm{T}$ cell subset compared with other known Th cells. We performed a microarray analysis comparing Th9 $9^{\mathrm{IL}-4+\mathrm{IL}-1} \beta$ cells with Th1, Th2, classic Th9 ${ }^{\mathrm{IL}-4+\mathrm{TGF}-} \beta$ cells, and Th9 ${ }^{\text {IL- } 4+\text { TGF- } \beta+\text { IL- } 1 \beta}$ cells (generated in the presence of TGF- $\beta$ together with IL- 4 and IL-1 $\beta$, in which IL- $1 \beta$ serves a stimulator to further enhance the IL- 9 expression from classic Th9 ${ }^{\text {IL- }} 4+$ TGF- $\beta$ cells $\left.{ }^{19,20}\right)$. Clustering analysis indicated that Th9 $9^{\mathrm{IL}-4+} \mathrm{IL}-1 \beta$ cells have a gene signature that is distinct from any other four types of Th cells (Fig. 2a). Gene clustering also identified three gene clusters (clusters 2, 4, and 6) enriched in these unique genes that are specifically upregulated in Th9 $9^{\mathrm{IL}-4+\mathrm{IL}-1 \beta}$ cells. These three clusters were further explored using commonality analysis ${ }^{21}$ and overlap among the three cell types Th2, classic Th9IL-4+TGF- $\beta$, and Th9 $9^{\mathrm{IL}-4+\mathrm{IL}-1 \beta}$ were analyzed by Venn diagrams. We detected 304,7 , and 12 overlapping transcriptional changes between Th9IL-4+IL-1 $\beta$ cells and Th2 cells in clusters 2,4 , and 6 , respectively; whereas only 1,1 , and 3 genes in clusters 2,4 , and 6 , respectively, were identified as overlapping transcriptional changes between Th9 $9^{\mathrm{IL}-4+\mathrm{IL}-1 \beta}$ cells and classic Th9 $9^{\mathrm{IL}-4+\mathrm{TGF}-} \beta$ cells (Fig. 2b-d). Of note, these overlapping genes in clusters 2,4 , and 6 only account for $\sim$ about $6 \%$ of all unique genes in Th9 $9^{\mathrm{IL}-4+\mathrm{IL}-1 \beta}$ cells, suggesting that they may represent a separate $\mathrm{T}$ cell phenotype. Next, we analyzed global gene expression in Th9 $9^{\mathrm{IL}}-4+\mathrm{IL}-1 \beta$ and classic Th $9^{\mathrm{IL}-4+\mathrm{TGF}-\beta}$ cells. Th9 ${ }^{\mathrm{IL}-4+} \mathrm{IL}-1 \beta$ cells possess $>50 \%$ differentially expressed genes compared to classic Th9 IL-4+TGF- $\beta$ cells (Fig. 2e). Apart from increased Il9 expression, Th9 $9^{\mathrm{IL}-4+\mathrm{IL}-1 \beta}$ cells also express markedly increased Csf2 (the gene that encodes GM-CSF), which is reported to be a unique gene induced by IL- $1 \beta^{22,23}$. By contrast, classic Th9 $9^{\mathrm{IL}-4+\mathrm{TGF}-\beta}$ cells show highly upregulated $N t 5 e$, the gene specifically promoted by TGF- $\beta^{24,25}$. Taken together, these data indicate that $\mathrm{Th} 9^{\mathrm{IL}-4+\mathrm{IL}-1 \beta}$ cells have 
a

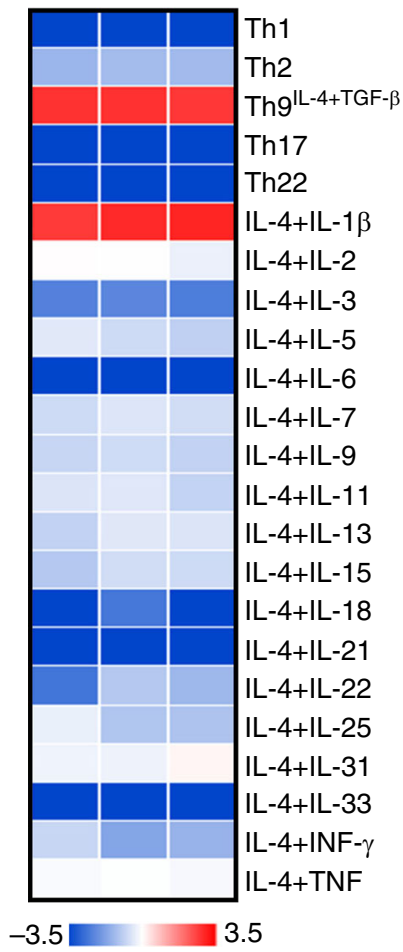

b

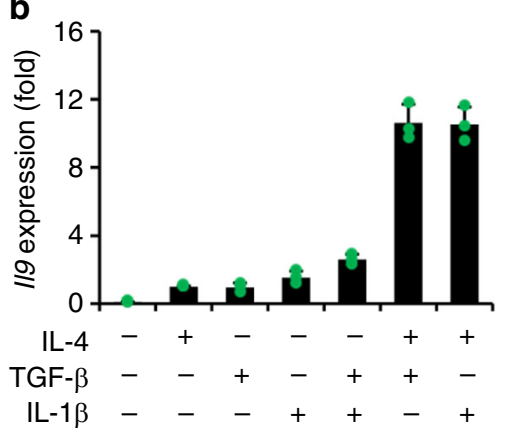

d
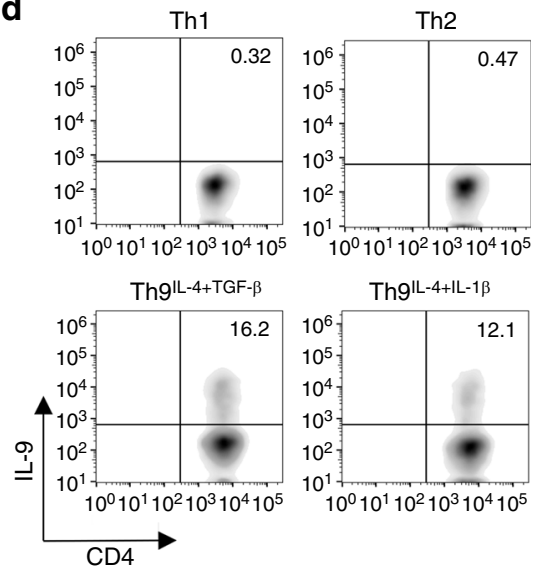

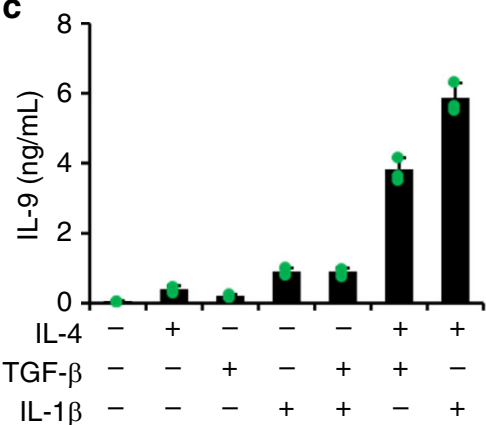

e

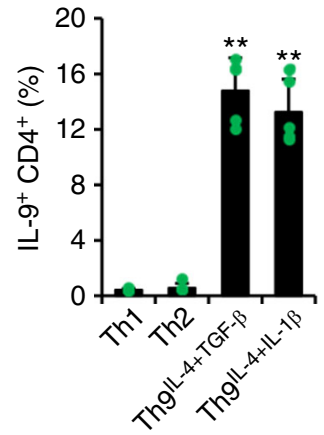

Fig. 1 Interleukin (IL)-4 in combination with IL-1 $\beta$ promotes IL-9-producing CD4 ${ }^{+}$T cell development. Naive CD4 ${ }^{+}$CD62 ${ }^{+} \mathrm{T}$ cells were purified from the spleens of tyrosinase-related protein-1 mice and cocultured with irradiated antigen-presenting cells under polarized conditions as detailed in the Methods section (polarized in vitro for 3 days). a Reverse transcriptase-PCR (RT-PCR) was performed to determine the expression of $1 / 9$ genes. Shown is the heatmap illustrating the relative expression of $1 / 9$ (data are log scaled) $(n=3)$. $\mathbf{b}$ RT-RCR analysis of $\| 9$ expression in T cells primed with different cytokines as indicated $(n=3)$. c IL-9 production was measured by enzyme-linked immunosorbent assay in the supernatants of differentiated T cells in vitro ( $n=3$ ).

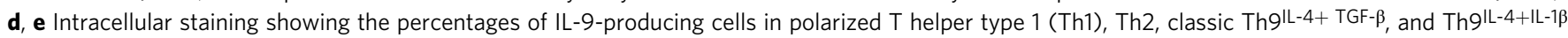
cells $(n=5)$. Representative data (d) and summarized results (e) are shown. Representative results of one from at least two repeated experiments are shown. Data are mean \pm SD; ${ }^{\star \star} P<0.01$, compared with Th1 or Th2 cells, Student's $t$ test

an identifiable transcriptional signature that may result in unique functional properties.

Th9 $9^{\mathrm{IL}-4+\mathrm{IL}-1 \boldsymbol{\beta}}$ cell generation is independent of TGF- $\beta$ signaling. Endogenously produced TGF- $\beta$ may contribute to IL-9 production from Th9 IL-4+IL-1 $\beta$ cells. To explore the contribution of endogenous TGF- $\beta$ signaling, we first analyzed the IL- $1 \beta$ and TGF- $\beta$ signaling pathway signatures in these Th cells. Using gene set enrichment analysis (GSEA), gene sets defined as in the IL-1signaling pathway were imprinted in Th9 $9^{\mathrm{IL}-4+\mathrm{IL}-1 \beta}$ cells compared to classic Th9IL-4+TGF- $\beta$ cells and in all other Th cells (including Th1, Th2, and Th9 ${ }^{\mathrm{IL}-4+\mathrm{TGF}-} \beta+\mathrm{IL}-1 \beta$ cells) (Fig. $3 \mathrm{a}$ ). As expected, TGF- $\beta$ signaling signature was markedly downregulated in Th9 ${ }^{\mathrm{IL}-4+\mathrm{IL}-1 \beta}$ cells compared to classic Th9 ${ }^{\mathrm{IL}}-4+\mathrm{TGF}-\beta$ cells or Rest Th cells (Fig. $3 \mathrm{~b}$ ). Thus we hypothesize that TGF- $\beta$ signaling is not required to produce IL- 9 in Th $9^{\mathrm{IL}-4+\mathrm{IL}-1 \beta}$ cells. To test our hypothesis, we generated Th9 $9^{\mathrm{IL}-4+\mathrm{IL}-1 \beta}$ cells in the presence of TGF- $\beta$ receptor serine kinase inhibitor (TGF- $\beta$ Ri). TGF- $\beta$ Ri treatment significantly downregulated Il9 gene expression and IL-9 secretion in the classic Th9 IL-4+TGF- $\beta$ cells but did not change IL-9 production in Th9 $9^{\text {IL- } 4+\mathrm{IL}-1 \beta}$ cells (Fig. 3c, d). To address the off-target potential of a chemical inhibitor, we also used antiTGF- $\beta$ antibody or CD4dnTGF-bRII mice. TGF- $\beta$ neutralization abrogated IL-9 production in classic Th9 $9^{\mathrm{IL}-4+\mathrm{TGF}-} \beta$ cells, while IL9 production in Th9 $9^{\mathrm{IL}-4+\mathrm{IL}-1 \beta}$ cells was not affected (Fig. 3e, f). Similar results were obtained when using naive TGF- $\beta$ RII ${ }^{\text {null }}$
$\mathrm{CD}^{+}{ }^{+} \mathrm{T}$ cells isolated from CD4dnTGF- $\beta$ RII mice. IL-9 production was markedly reduced in classic Th9 $9^{\mathrm{IL}-4+\mathrm{TGF}-\beta}$ cells but not in Th9IL-4+IL-1 $\beta$ cells generated from TGF- $\beta$ RIInull $\mathrm{CD}^{+} \mathrm{T}$ cells (Fig. $3 g, h$ ). To exclude the possibility that IL- $1 \beta$ promotes the production of other TGF- $\beta$ superfamily ${ }^{17}$ and then indirectly induces IL-9 production, we checked the activation status of Smads in Th9 $9^{\mathrm{IL}-4+\mathrm{IL}-1 \beta}$ cells compared to classic Th9 $9^{\mathrm{IL}-4+\mathrm{TGF}-} \beta$ cells. As shown in Supplementary Figure 8, Th9 $9^{\mathrm{IL}-4+\mathrm{TGF}-} \beta$ but not Th9 $9^{\mathrm{IL}-4+}$ IL-1 $\beta$ cells had activated Smads, and as expected, Smad inhibitors had little impact on IL-9 production in Th9IL-4+ IL-1 $\beta$ cells. Collectively, these results suggested that IL- 4 plus IL- $1 \beta$ can effectively induce generation of Th9 cells without TGF- $\beta$ signaling.

$\mathrm{NF}-\kappa \mathrm{B}$ pathway is required for Th $9^{\mathrm{IL}-4+\mathrm{IL}-1 \beta}$ cell generation. It is also important to determine what signaling pathway(s) is responsible for IL-9 production from Th9 $\mathrm{IL}^{\mathrm{IL}} 4+\mathrm{IL}-1 \beta$ cells. We first checked Irf1, because it has been reported to regulate IL-9 production in Th9 $9^{\mathrm{IL}-4+\mathrm{TGF}-\beta+\mathrm{IL}-1 \beta}$ cells $^{20}$. However, we found no difference between IL-9 production in Th9 $9^{\mathrm{IL}-4+\mathrm{IL}-1 \beta}$ cells generated from naive $\mathrm{CD}^{+}{ }^{+} \mathrm{T}$ cells isolated from WT mice or Irf1-knockout mice (Supplementary Figure 9). To identify the potential pathway for IL-9 induction, we performed GSEA for enriched signaling(s) in Th9 $9^{\mathrm{IL}-4+\mathrm{IL}-1 \beta}$ cells (674 Reactome and 186 KEGG gene sets). As shown in Fig. 4a, b for the most upregulated/downregulated pathways, it seems that The NF- $\kappa$ B and AKT pathways were specifically activated in Th9 $9^{\mathrm{IL}}-4+\mathrm{IL}-1 \beta$ 
a

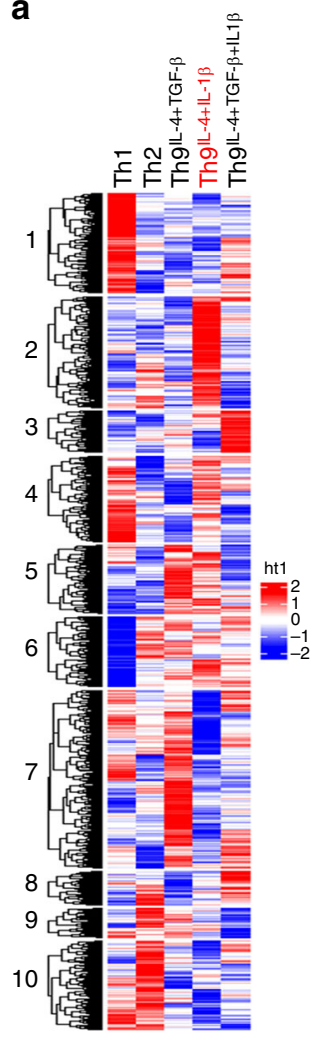

b

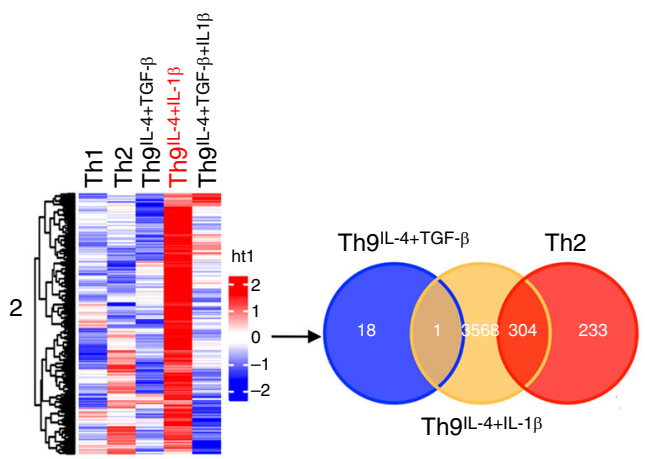

d

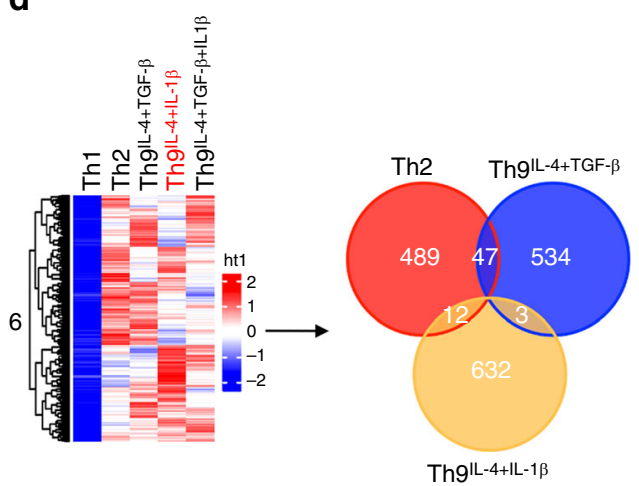

C

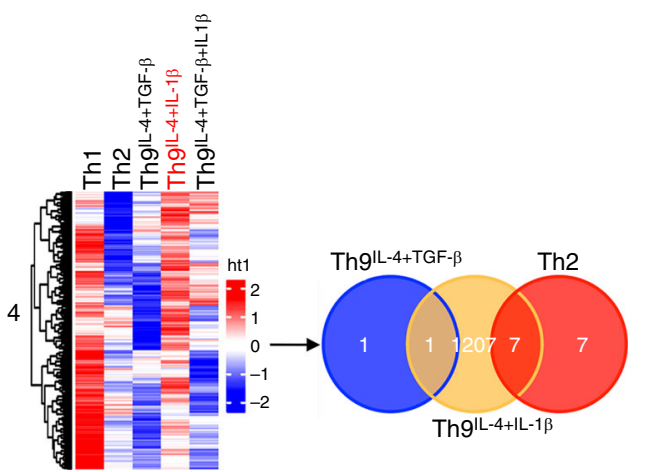

e

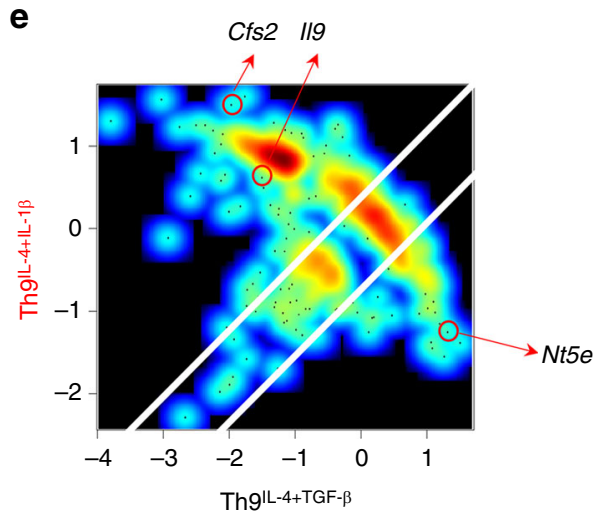

Fig. 2 Th9 ${ }^{\mid L-4+I L-1 \beta}$ cells have an identifiable transcriptional signature. Naive CD4 ${ }^{+} \mathrm{CD} 6 \mathrm{~L}^{+} \mathrm{T}$ cells were purified from the spleens of tyrosinase-related protein-1 mice and cocultured with irradiated antigen-presenting cells under polarized conditions for 3 days, and RNA was extracted for gene array analysis.

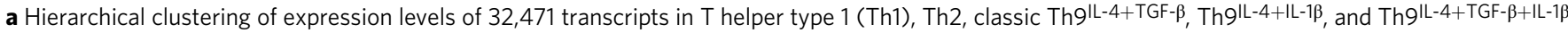
cells. Cut-tree algorithm divided the transcripts into 10 clusters according to the distances between them defined by average method. $\mathbf{b}$ Venn diagrams displaying the number of upregulated genes of Th2, classic Th9|L-4+TGF- $\beta$, and Th9lL-4+IL-1 $\beta$ cells in cluster 2 . The threshold for the upregulated genes is set as $z$-score $=0.9$. $\mathbf{c}$ Venn diagrams showing the number of upregulated genes of Th2, classic Th9lL-4+TGF- $\beta$, and Th9lL-4+IL-1 $\beta$ cells in cluster 4 . The threshold for the upregulated genes is set as $z$-score $=0.9$. $\mathbf{d}$ Venn diagrams showing the number of upregulated genes of Th2, classic Th9lL-4+TGF- $\beta$, and Th9lL-4+IL-1 $\beta$ cells in cluster 6 . The threshold for the upregulated genes is set as $z$-score $=0.9$. e Specific genes upregulated or downregulated by Th9lL-4+IL-1 $\beta$ cells versus classic Th9lL-4+TGF- $\beta$. Axis denotes the scaled expression levels represented by $z$-scores in the scatter plot. Csf2 and II9 are uniquely upregulated ( $z$-score is $>1$ and 0 , respectively) in Th9 ${ }^{\mathrm{L}-4+\mathrm{IL}-1 \beta}$ cells, whereas Nt5e is specifically upregulated in classic Th9lL-4+TGF- $\beta$ cells with $z$-score $>1$

cells compared with other Th cells. Using a panel of chemicals containing 82 pathway inhibitors (Supplementary Figure 10a), only the NF- $\mathrm{KB}$ pathway inhibitor QNZ significantly suppressed

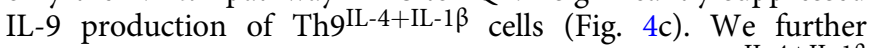
confirmed that inhibition of IL-9 production of Th9 $9^{\mathrm{IL}-4+\mathrm{IL}-1 \beta}$ cells by QNZ was dose dependent (Fig. 4d, e), whereas such effect on Th91L-4+TGF- $\beta$ cells was moderate in comparison to that of Th $9^{\mathrm{IL}-4+\mathrm{IL}-1 \beta}$ cells (Supplementary Figure 10b-10d). To further investigate the molecular requirement, we first used a luciferase reporter assay to examine which NF- $\mathrm{KB}$ family member(s) can bind and transcribe Il9 gene. We found RelA but not other members significantly enhanced the $I l 9$ promoter transcriptional activity (Supplementary Figure 11a). In addition, we detected a significantly increased binding of RelA to the Il9 promoter in Th9 $9^{\mathrm{IL}-4+\mathrm{IL}-1 \beta}$ cells by chromatin immunoprecipitation (ChIP) assay (Supplementary Figure 11b). Finally, knockdown of RelA by small interfering RNA (siRNA) largely reduced IL-9 production in Th $9^{\mathrm{IL}-4+\mathrm{IL}-1 \beta}$ cells (Supplementary Figure 11c). Therefore, these data suggest that activation of the NF- $\kappa B$ pathway is required for IL-9 production in Th $9^{\mathrm{IL}-4+\mathrm{IL}-1 \beta}$ cells.

Th9IL-4+IL-1 $\beta$ cells have a cytolytic effector signature. Our group has a long-term interest in using tumor-specific Th9 cells as a novel therapeutic strategy for malignancies $7,13,15,26,27$. We next investigated whether these TGF- $\beta$ signaling-independent Th9 $9^{\mathrm{IL}-4+\mathrm{IL}-1 \beta}$ cells are also potent antitumor T cells. Analysis of gene array data suggests that most exhaustion/inhibition markers are downregulated in Th9 $9^{\mathrm{IL}-4+\mathrm{IL}-1 \beta}$ cells compared to classic Th9IL-4+TGF- $\beta$ cells, including Ctla4, Pdcd1, Lag3, and NT5e (Fig. 5a). In particular, Th9iL-4+IL-1 $\beta$ cells had greater expression of Eomes and Tbx21 (Fig. 5b), transcriptional factors that suggest effector cell development ${ }^{28-30}$, and increased expression of a Grz panel (Grza, Grzb, Grzc, Grzd, Grze, Grzf, Grzg) and Prf1 (Fig. 5c). Enhanced expression of cytokine genes, such as $I l 9, I l 2$, and $I l 21$, may also be involved in the superior antitumor functionality of Th9 $9^{\mathrm{LL}-4+\mathrm{IL}-1 \beta}$ cells. These observations prompted us to use GSEA to generate an enrichment plot for a cytolytic effector T cell gene signature. GSEA of the gene array data revealed that, as compared with the classic Th9 $9^{\text {IL-4+TGF- } \beta}$ cells, the cytolytic effector T cell gene signature was significantly enriched in Th9 $9^{\mathrm{IL}-4+\mathrm{IL}-1 \beta}$ cells (Fig. $5 \mathrm{~d}$ ), further suggesting that $\mathrm{Th} 9^{\mathrm{IL}-4+\mathrm{IL}-1 \beta}$ cells are also potent antitumor effector T cells. Indeed, tumor-specific Th9 $9^{\mathrm{IL}-4+\mathrm{IL}-1 \beta}$ cells displayed significantly higher tumor-specific killing activity compared to classic Th9 9 LL-4+TGF- $\beta$ and Th2 cells in the in vitro cytolytic killing assay (Fig. 5e, f and Supplementary Figure 12a). 
a

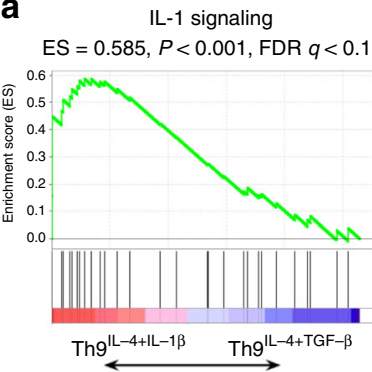

C



f



\section{IL-1 signaling}

$\mathrm{ES}=0.522, P<0.001$, FDR $q<0.1$



d



b TGF- $\beta$ signaling pathway $\mathrm{ES}=0.372, P<0.001$, FDR $q<0.1$

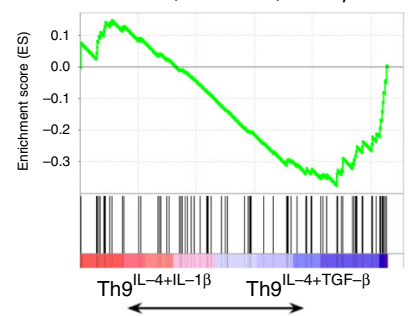

TGF- $\beta$ signaling pathway

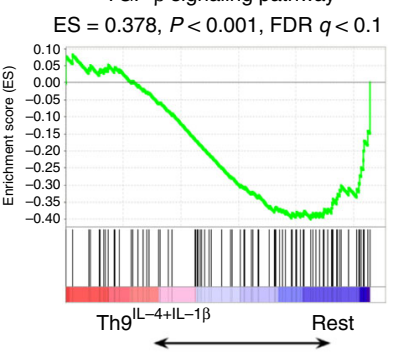

e
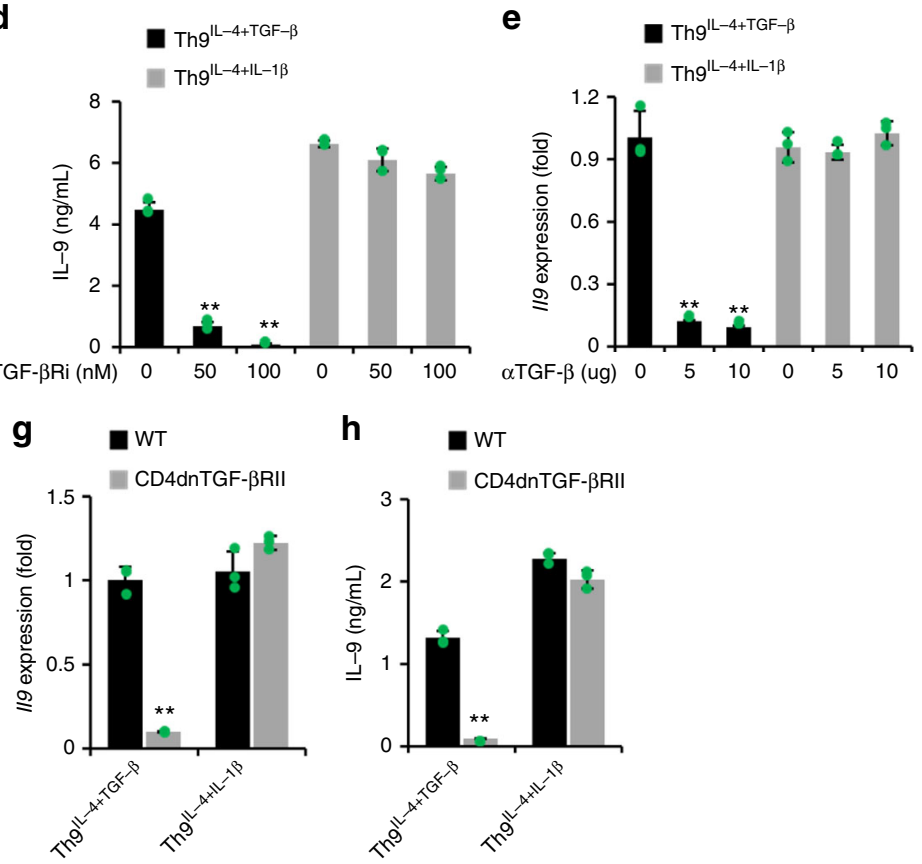

Fig. 3 Differentiation of Th9lL-4+IL-1 $\beta$ cells is transforming growth factor (TGF)- $\beta$ independent. a-f T cells differentiation and gene array data are the same as shown in Fig. 2. a Gene set enrichment analysis (GSEA) of Th9lL-4+IL-1 $\beta$ cells versus classic Th9lL-4+TGF- $\beta$ cells or the Rest T helper (Th) cells for interleukin (IL)-1 signaling genes. Rest Th cells contain Th1, Th2, Th9lL-4+TGF- $\beta$, and Th9lL-4+TGF- $\beta+$ IL-1 $\beta$ cells. b GSEA of Th9lL-4+IL-1 $\beta$ versus classic Th9lL-4+TGF- $\beta$ cells or the Rest Th cells for TGF- $\beta$ signaling genes. c, d Reverse transcriptase-PCR (RT-PCR) analysis of $/ 19$ transcriptional level (c) and enzyme-linked immunosorbent assay (ELISA) of IL-9 production in the supernatants (d) from TGF- $\beta$ Ri-treated classic Th9IL-4+TGF- $\beta$ cells or Th9IL-4+IL-1 $\beta$ cells at the indicated concentrations $(n=3)$. TGF- $\beta$ Ri TGF- $\beta$ receptor serine kinase inhibitor. e, $\mathbf{f}$ RT-PCR analysis of $/ 19$ transcriptional level (e) and ELISA of IL-9 production in the supernatants $(\mathbf{f})$ from $\alpha$ TGF- $\beta$-treated classic Th9lL-4+TGF- $\beta$ cells or Th9lL-4+IL-1 $\beta$ cells at the indicated concentrations ( $n=3$ ). $\alpha$ TGF- $\beta$ TGF- $\beta$ monoclonal antibody (mAb). $\mathbf{g}$, h Naive CD4+ CD62L+ T cells were purified from the spleens of wild-type (WT) mice or CD4dnTGF- $\beta$ RII mice and cultured with plate-bound anti-CD3 mAbs and soluble anti-CD28 mAbs under polarized conditions, as detailed in the Methods section, for 3 days. RT-PCR analysis of $1 / 9$ transcriptional level ( $\mathbf{g}$ ) and ELISA of IL-9 production in the supernatants (h) of classic Th9lL-4+TGF- $\beta$ cells and Th9IL-4+IL-1 $\beta$ cells from WT mice or CD4dnTGF- $\beta$ RII mice after in vitro differentiation $(n=3)$. CD4dnTGF- $\beta$ RII mice mice expressing a dominant-negative TGF- $\beta$ receptor. Data are mean $\pm \mathrm{SD} ;{ }^{\star \star} P<0.01$, Student's $t$ test. Representative results of one from two repeated experiments are shown

Th9 $9^{\text {IL-4 }+ \text { IL-1 } \beta}$ cells are potent antitumor $\mathbf{T}$ cells. Next, we investigated whether tumor-specific Th $9^{\mathrm{IL}-4+\mathrm{IL}-1 \beta}$ cells possess antitumor capacity in vivo. We used the TRP-1 model of adoptive immunotherapy, which reproduces the clinical challenge of targeting gp75 tumor/self-antigen in the poorly immunogenic B16 melanoma model ${ }^{15}$. We transferred TRP-1-specific Th2 cells or classic Th9IL-4+TGF- $\beta$ cells or Th9IL- $4+$ IL-1 $\beta$ cells into B6 mice bearing 6-day established B16 lung metastatic murine melanoma. Analyzing the lung tumor foci on 16 days after tumor inoculation suggested that Th9 $9^{\mathrm{IL}-4+\mathrm{IL}-1 \beta}$ cells induced robust tumor clearance compared to phosphate-buffered saline (PBS) or Th2 cell-treated groups (Fig. 6a and Supplementary Figure $12 \mathrm{~b})$, and Th9 $9^{\mathrm{IL}-4+\mathrm{IL}-1 \beta}$ cells also showed superior longterm (40 days) antitumor capacity compared to classic Th9 $9^{\mathrm{IL}-4+\mathrm{TGF}-\beta}$ cells (Fig. $6 \mathrm{~b}$ ). In addition, on day $80,70 \%$ of Th9 $9^{\text {IL-4+IL- } 1 \beta}$ cell-treated mice were alive versus $30 \%$ of mice

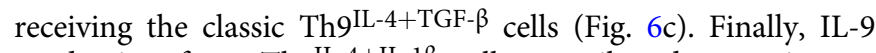
production from Th9 $9^{\mathrm{IL}-4+\mathrm{IL}-1 \beta}$ cells contributed to antitumor efficacy, since neutralization of IL-9 reduced survival of Th9 $9^{\mathrm{IL}-4+\mathrm{IL}-1 \beta}$ cell-treated mice (Fig. 6d). Overall, our study indicates that Th9 $9^{\mathrm{IL}-4+\mathrm{IL}-1 \beta}$ cells are less exhausted $\mathrm{T}$ cells endowed with a cytotoxic $\mathrm{T}$ effector gene signature that can exert a superior antitumor response compared to classic Th9 $9^{\mathrm{IL}-4+\mathrm{TGF}-} \beta$ cells.

\section{Discussion}

IL- 4 and TFG- $\beta$ have long been considered as the two essential cytokines to induce Th9 cell differentiation. Although additional cytokines (e.g., type I interferon (IFN), IL-1, IL-2, and IL-25) ${ }^{9,19,20,31,32}$ and costimulatory signaling (e.g., OX40 and GITR) 33-35 enhance IL-9 production and Th9 cell differentiation, the 
a

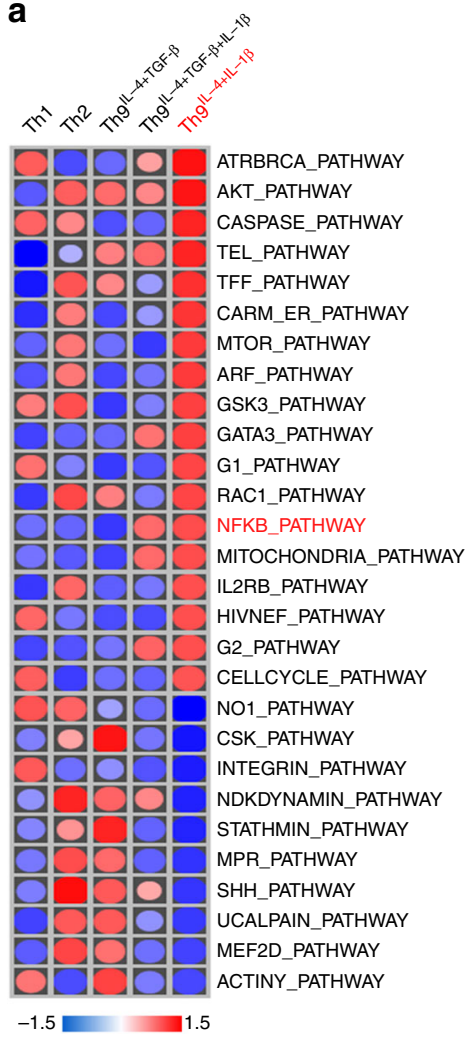

b

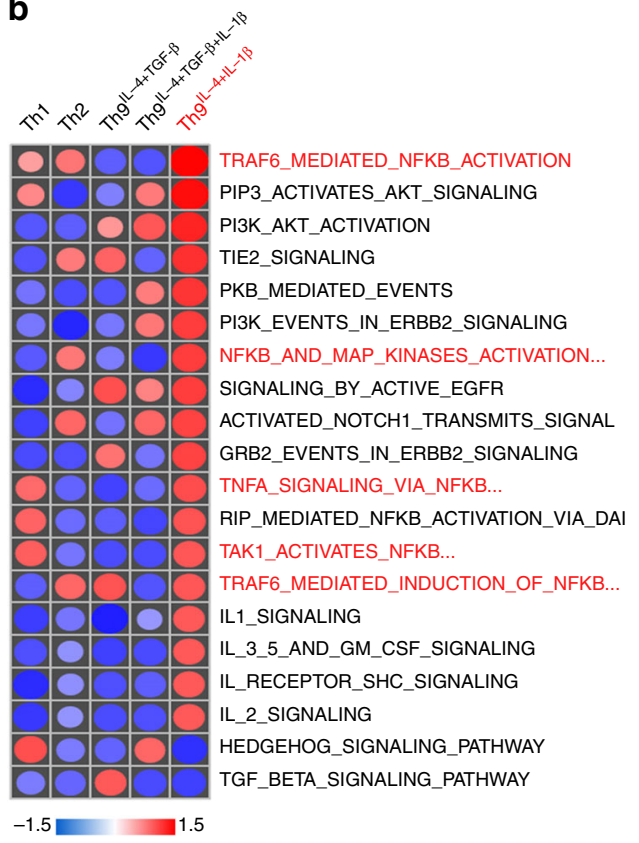

C
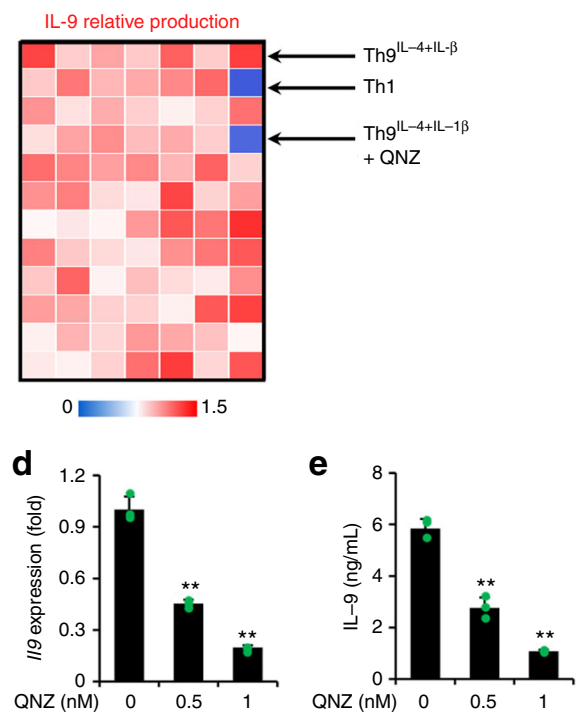

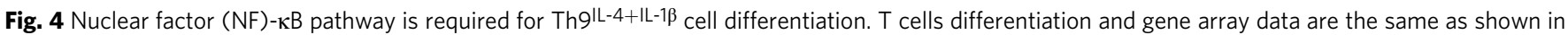
Fig. 2. a, b Heatmaps of enriched signaling of the most upregulated/downregulated pathways for T helper type 1 (Th1), Th2, classic Th9lL-4+TGF- $\beta$, Th9lL-4 $+\mathrm{IL}-1 \beta$, and Th9lL-4+TGF- $\beta+\mathrm{IL}-1 \beta$ cells. $\mathbf{c}$ Interleukin (IL)-9 production was measured by enzyme-linked immunosorbent assay (ELISA) in the supernatants of in vitro differentiated T cells. Shown is the heatmap of IL-9 relative production in the supernatants of Th1 and Th9 ${ }^{\mathrm{IL}-4+\mathrm{IL}-1 \beta}$ cells and inhibitor-treated Th9lL$4+I L-1 \beta$ cells (Kinase Inhibitor library, also see Supplementary Figure 10a). d, e RT-PCR analysis of $/ 19$ transcriptional level (d) and ELISA of IL-9 production

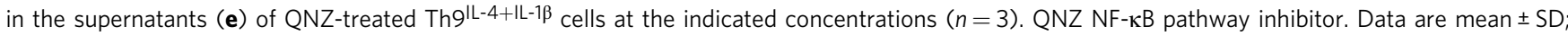
${ }^{\star \star} P<0.01$, Student's $t$ test. Representative results from one of two repeated experiments are shown

studies were performed in the context of the standard cytokine milieu containing IL-4 and TGF- $\beta$. No study has thus far investigated whether IL- 4 or TGF- $\beta$ is replaceable for Th9 induction. In the current study, we, for the first time, found that Th9 cell development can occur in the absence of TGF- $\beta$ signaling. When TGF- $\beta$ has been replaced by IL-1 $\beta$, differentiation of IL-9-producing T cells can be achieved. The presence of APCs may further facilitate Th9 ${ }^{\mathrm{IL}}-4+\mathrm{IL}-1 \beta$ cell differentiation, which may be a synergistic effect of APC-induced costimulation upon IL- $1 \beta$ stimulation. Our study provides new insight into Th9 cell development and may be crucial to understanding the signaling pathways that regulate Th9 cell fate and functions.

Our new Th9 $9^{\mathrm{IL}-4+\mathrm{IL}-1 \beta}$ cells may represent a completely separate T cell phenotype compared to classic Th9 ${ }^{\mathrm{IL}-4+\mathrm{TGF}-} \beta$ cells and other known Th subsets (Th1 and Th2 cells). This is supported by our gene array analysis of the global gene profile of Th9IL-4+IL-1 $\beta$ cells. We distinguished 3 gene clusters with key gene features of Th9 $9^{\mathrm{IL}-4+\mathrm{IL}-1 \beta}$ cells, within which only $\sim 6 \%$ of the unique genes are shared with Th2 or classic Th9IL-4+TGF- $\beta$ cells. When directly compared with the classic Th9 $9^{\mathrm{IL}-4+\mathrm{TGF}-\beta}$ cells, the new Th9 ${ }^{\mathrm{IL}-4+\mathrm{IL}-1 \beta}$ cells display a large portion of differentially expressed genes. As expected, Th9 $9^{\mathrm{IL}-4+\mathrm{IL}-1 \beta}$ cells are imprinted with the IL-1 signaling pathway signature while the classic Th9 ${ }^{\mathrm{IL}-4+\mathrm{TGF}-} \beta$ cells are enriched in the TGF- $\beta$ signaling signature; this may be caused by the different priming cytokine signaling from IL- $1 \beta$ versus TGF- $\beta$. Our study also excluded the possibility that endogenously produced TGF- $\beta$ or endogenous TGF- $\beta$ superfamily member signaling in naive $\mathrm{CD}^{+}{ }^{+} \mathrm{T}$ cells contribute to IL-9 production in Th9IL-4+IL-1 $1 \beta$ cells. These studies indicate Th9 $9^{\mathrm{IL}}-4+\mathrm{IL}-1 \beta$ cells are phenotypically different from TGF- $\beta$-dependent classic Th9IL-4+TGF- $\beta$ cells.

For development of classic Th $9^{\mathrm{IL}-4+\mathrm{TGF}-\beta}$ cells, a large number of signaling molecules has been reported to be crucial for IL-9 transcription, including those downstream of IL-4 signaling (e.g., signal transducer and activator of transcription factor 6 (STAT6) and GATA3), TGF- $\beta$ signaling (e.g., PU.1, TAK1, HIF1a, and SMAD), and common signaling/transcriptional factors in T cells (e.g., IRF4, BATF, STAT5, AKT, FOXO1, NFAT, and Notch $)^{7,8,10,36}$. Thus it appears that IL-9 production or Th9 $9^{\text {IL- } 4+\text { TGF- } \beta}$ cell differentiation is not regulated by a master transcription factor but instead by a coordinated network. Using GSEA, we identified markedly enriched NF- $\kappa B$ and AKT pathway signatures in Th9IL-4+IL-1 $\beta$ cells. After adding a panel of individual inhibitors at the beginning of the Th9 $9^{\mathrm{IL}-4+\mathrm{IL}-1 \beta}$ cell priming, we confirmed that IL- 9 production depended on NF- $\kappa$ B. It has been reported that a variety of immunologically relevant ligands, like IL-1 family members, TNF family members, etc., can activate $N F-\kappa B$ pathway ${ }^{37}$. Our results suggest that NF- $\kappa B$ family member RelA is required for IL-9 production in Th9IL-4+ IL- $1 \beta$ cells. However, RelB/p52 has been reported to be more active than RelA/p50 for IL- 9 production in Th $9^{\mathrm{IL}-4+\mathrm{TGF}-\beta}$ cells upon OX40 costimulation $^{33}$. This may be a result of different epigenetic 

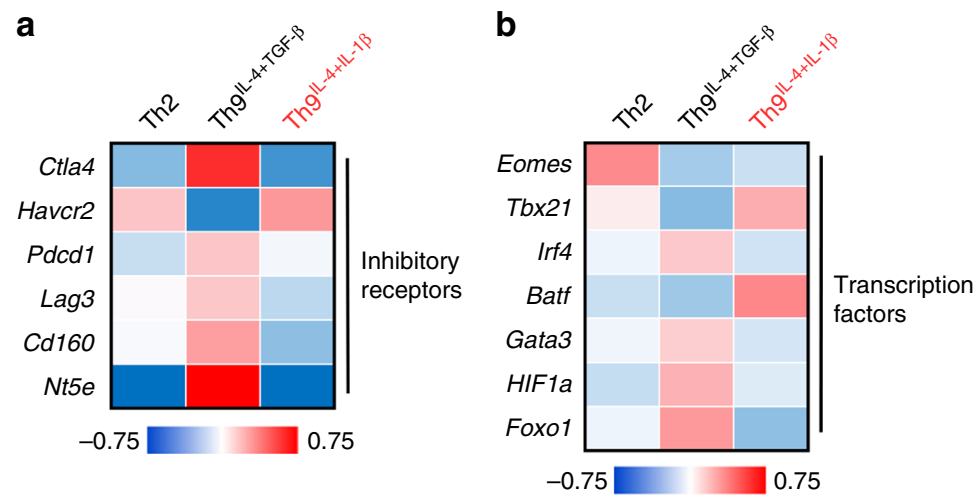

\section{d}

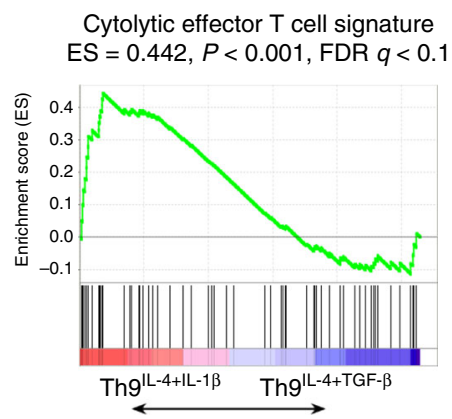

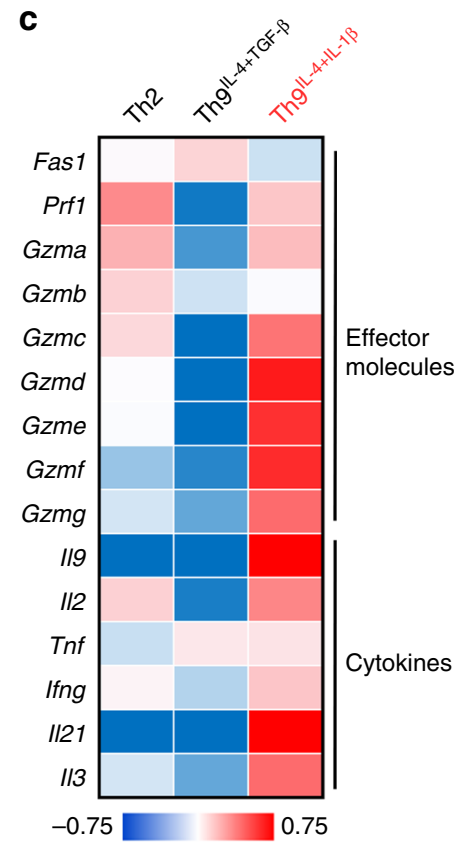

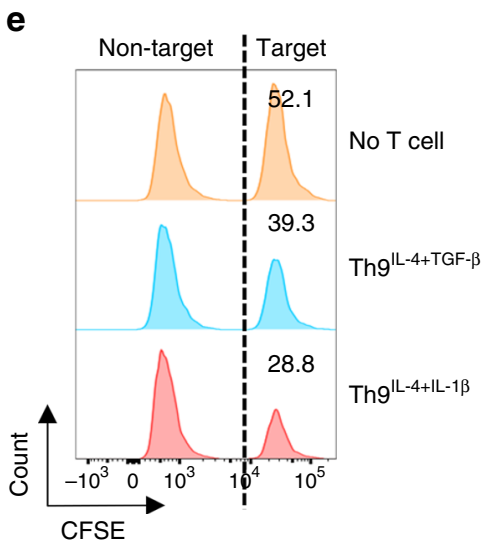

$\mathbf{f}$

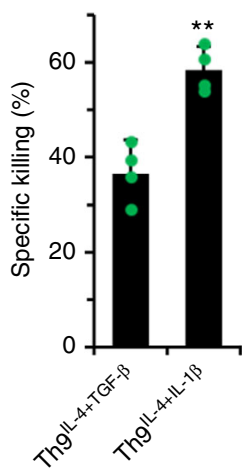

Fig. 5 Th9 $9^{\mathrm{L}-4+\mathrm{IL}-1 \beta}$ cells exhibited antitumor activity in vitro. T cells differentiation and gene array data are the same as shown in Fig. 2. a Heatmap illustrating the relative expression of exhaustion/inhibition markers as indicated (data are log scaled). $\mathbf{b}$ Heatmap illustrating the relative gene expression of transcription factors as indicated (data are log scaled). c Heatmap illustrating the relative gene expression (data are log scaled). $\mathbf{d}$ Gene set enrichment analysis of classic Th9 ${ }^{\mathrm{LL}-4+\mathrm{TGF}-\beta}$ cells versus Th9 ${ }^{\mathrm{LL}-4+\mathrm{IL}-1 \beta}$ cells for cytolytic effector T cell signature. e, $\mathbf{f}$ Specific killing assay of tyrosinase-related protein-1 classic Th9lL-4+TGF- $\beta$ or Th9lL-4+IL-1 $\beta$ was performed against CFSEhigh-B16 tumor cells as target cells and CFSElow-MC38 tumor cells as a non-target control. An E:T ratio of 10:1 was used, and specific killing was determined after $48 \mathrm{~h}$ of coculture. Representative data (e) and summarized data (f) are shown $(n=4)$. Data are mean \pm SD; ${ }^{\star \star} P<0.01$, Student's $t$ test. Representative results from one of two repeated experiments are shown

changes of $\mathrm{Il} 9$ gene promoter region in $\mathrm{Th} 9^{\mathrm{IL}-4+\mathrm{IL}-1 \beta}$ versus Th9 IL-4+TGF- $\beta$ cells, which allows unique binding accessibilities for different NF- $\kappa B$ family members. Thus signaling through the NF- $\kappa$ B pathway, mainly RelA, is essential for Il9 transcription and IL-9 production in the Th9 $9^{\mathrm{IL}-4+}$ IL-1 $\beta$ cells.

Our long-term interest in Th9 cells is to explore their potential for cancer treatment ${ }^{7,13,15,26,27}$. Thus we investigated whether Th9 $9^{\mathrm{IL}-4+\mathrm{IL}-1 \beta}$ cells are also tumor killers. Interestingly, these cells display attractive antitumor effector $\mathrm{T}$ cell features, such as further downregulated expression of exhaustion markers and high enrichment in cytolytic effector $\mathrm{T}$ cell gene signatures, compared to classic Th9 $9^{\mathrm{IL}-4+\mathrm{TGF}-\beta}$ cells. Direct comparisons of these two phenotypically distinct Th9 cells suggests that Th9 ${ }^{\mathrm{IL}}-4+\mathrm{IL}-1 \beta$ cells display higher tumor-specific cytotoxicity in vitro and improved tumor clearance in vivo compared to classic Th9 $9^{\mathrm{IL}-4+\mathrm{TGF}-\beta}$ cells. Of note, Th9 $9^{\mathrm{IL}-4+\mathrm{IL}-1 \beta}$ cell-mediated therapeutic antitumor effects also require IL-9 production. Therefore, our study indicates that Th9 $9^{\mathrm{IL}-4+\mathrm{IL}-1 \beta}$ cells are less exhausted cytotoxic effector $\mathrm{T}$ cells and can exert an antitumor response superior to classic Th9 $9^{\mathrm{IL}-4+\mathrm{TGF}-\beta}$ cells.

In summary, we report for the first time that TGF- $\beta$ is not indispensable for Th9 cell differentiation. IL- 4 plus IL- $1 \beta$ effectively induced IL- 9 production independently of TGF- $\beta$ signaling. Our study further showed that the NF- $\kappa$ B pathway, mainly RelA, is required for IL- 9 production of Th $9^{\mathrm{IL}-4+\mathrm{IL}-1 \beta}$ cells. Noticeably, tumor-specific Th9 $9^{\mathrm{IL}-4+\mathrm{IL}-1 \beta}$ cells are cytolytic effectors and endowed with robust antitumor function. Therefore, our findings confirm the current understanding underlying Th9 cell differentiation and provide an avenue for a potentially more powerful weapon for cancer immunotherapy.

\section{Methods}

Mice. C57BL/6, B6.Cg-Tg(Cd4-TGFBR2)16Flv/J, B6.129S2-Irf1 tm1Mak/J, B6.Cg-Tg

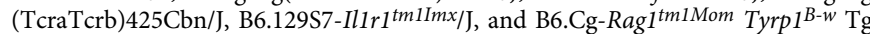
(Tcra,Tcrb)9Rest/J mice were purchased from The Jackson Laboratory. Male and female 6-8-week-old mice were used for each animal experiment. All experiments 
a

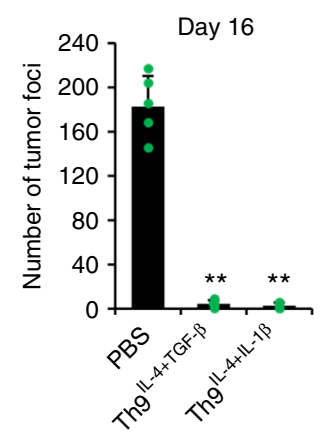

b

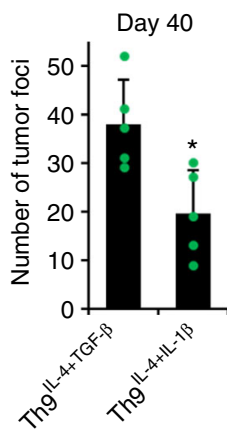

C

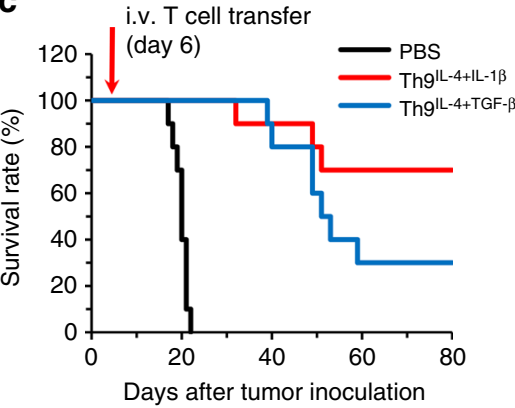

d



Fig. 6 The antitumor activity of Th9 $9^{\mathrm{L}-4+\mathrm{IL}-1 \beta}$ cells in vivo. C57BL/6 mice were challenged with $1 \times 10^{5}$ B16 cells delivered intravenously. T cells were differentiated as in Fig. 2, and $1 \times 10^{6}$ tyrosinase-related protein (TRP)-1 T cells were transferred on day 6 after tumor challenge. a, b TRP-1-specific classic Th9lL-4+TGF- $\beta$ cells or Th9lL-4+IL-1 $\beta$ cells were transferred into tumor-bearing mice, tumor foci in the lung were counted on day 16 (a) or day 40 (b) after tumor inoculation ( $n=5$ mice/group). c The survival rate of tumor-bearing mice with the indicated treatments $(n=10$ mice). $\mathbf{d}$ The survival rate of tumorbearing mice with the indicated treatments $(n=10$ mice). Control IgG or $\alpha$ IL-9 were injected intraperitoneally twice every week starting at 1 day before intravenous transfer of $T$ cells. Data are mean \pm SD; ${ }^{\star} P<0.05,{ }^{\star \star} P<0.01$, Student's $t$ test. Representative results from one of two repeated experiments are shown

complied with protocols approved by the Institutional Animal Care and Use Committee at the Wake Forest School of Medicine.

Cell lines. B16 melanoma cell line was purchased from ATCC; MC-38 cell line was a gift from Dr.Patrick Hwu, MD Anderson Cancer Center. Cells were cultured in Iscove's Modified Dulbecco's Medium (Invitrogen) or RPMI 1640 Medium (Invitrogen) supplemented with 10\% heat-inactivated fetal bovine serum (ThermoFisher Scientific), $100 \mathrm{U} / \mathrm{ml}$ penicillin-streptomycin, and $2 \mathrm{mM}$ L-glutamine (both from Invitrogen).

Reagents. TGF- $\beta$ receptor serine kinase inhibitor TGF- $\beta$ Ri (Cat\#616452) was purchased from Millipore. NF- $\kappa B$ inhibitor QNZ (Cat\#sc-200675) was purchased from Santa Cruz Biotechnology. Smad3 inhibitor SIS3 (Cat\#S7959) and Smad2 inhibitor LY2109761 (Cat\#S2704) were purchased from Selleckchem. The major histocompatibility complex (MHC) class II-restricted TRP-1 $1^{106-130}$ peptides (SGHNCGTCRPGWRGAACNQKILTVR) and the MHC class II-restricted OT II ${ }^{323-339}$ peptides (ISQAVHAAHAEINEAGR) were purchased from GenScript. Mouse IL-4-neutralizing antibody (clone 11B11), mouse IFN- $\gamma$-neutralizing antibody (clone XMG1.2), mouse IL-9-neutralizing antibody (clone 9C1), mouse CD4 depletion antibody (clone GK1.5), and TGF- $\beta$-neutralizing antibody (clone 1D11.16.8) were purchased from BioXcell. Mouse cytokine IL-1 $\beta$, IL-4, IL-6, IL-12, and TNF and human IL-2 and TGF- $\beta$ were purchased from R\&D Systems. Chemical inhibitor Panel (Enzo, SCREEN-WELL ${ }^{\circledR}$ Kinase Inhibitor library, Cat\#BML2832-0100; also see Supplementary Figure 7a).

In vitro Th cell differentiation. Naive $\mathrm{CD} 4{ }^{+} \mathrm{CD} 62 \mathrm{~L}^{+} \mathrm{T}$ cells were purified from the spleens of TRP-1 or OT II mice by isolation kit (STEMCELL Technologies, Cat\#19765) according to the manufacturer's protocol. TRP-1-specific naive CD4 $\mathrm{T}$ cells were cultured for 3 days with irradiated T cell-depleted splenic APCs from C57BL/6 mice in the presence of TRP-1 $1^{106-130}$ peptide $(5 \mu \mathrm{g} / \mathrm{ml})$ or OT II ${ }^{323-339}$ peptides $(5 \mu \mathrm{g} / \mathrm{ml})$. Th1 polarized medium was supplemented with IL-2 $(100 \mathrm{U} / \mathrm{ml})$, IL-12 $(5 \mathrm{ng} / \mathrm{ml})$, and anti-IL-4 mAbs $(10 \mu \mathrm{g} / \mathrm{ml})$. Th2 polarized medium was supplemented with IL-2 $(100 \mathrm{U} / \mathrm{ml}), \mathrm{IL}-4(10 \mathrm{ng} / \mathrm{ml})$ and anti-IFN- $\gamma \mathrm{mAbs}(10 \mu \mathrm{g} / \mathrm{ml})$. Th17 polarized medium was supplemented with IL-6 $(30 \mathrm{ng} / \mathrm{ml})$, TGF- $\beta$ $(2.5 \mathrm{ng} / \mathrm{ml})$, and anti-IFN- $\gamma \mathrm{mAbs}(10 \mu \mathrm{g} / \mathrm{ml})$. Th22 polarized medium was supplemented with IL-6 $(10 \mathrm{ng} / \mathrm{ml})$, TNF $(5 \mathrm{ng} / \mathrm{ml})$, and anti-IFN- $\gamma \mathrm{mAbs}(10 \mu \mathrm{g} / \mathrm{ml})$. Th9 $9^{\text {TGF- }-\beta+\mathrm{IL}-4}$ polarized medium was supplemented with IL-4 $(10 \mathrm{ng} / \mathrm{ml})$, TGF- $\beta$ $(1 \mathrm{ng} / \mathrm{ml})$, and anti-IFN- $\gamma \mathrm{mAbs}(10 \mu \mathrm{g} / \mathrm{ml})$.

Th9 $9 \mathrm{LL}-4+$ TGF- $\beta+\mathrm{IL}-1 \beta$ polarized medium was supplemented with IL-4 $(10 \mathrm{ng} / \mathrm{ml})$, TGF- $\beta(1 \mathrm{ng} / \mathrm{ml}), \mathrm{IL}-1 \beta(10 \mathrm{ng} / \mathrm{ml})$, and anti-IFN- $\gamma \mathrm{mAbs}(10 \mu \mathrm{g} / \mathrm{ml})$. Th9 $9^{\mathrm{IL}-4+\mathrm{IL}-1 \beta}$ polarized medium was supplemented with IL-4 $(10 \mathrm{ng} / \mathrm{ml}), \mathrm{IL}-1 \beta(10 \mathrm{ng} / \mathrm{ml}$, or used at the indicated concentrations), and anti-IFN $-\gamma$ mAbs $(10 \mu \mathrm{g} / \mathrm{ml})$. In some experiments, naive $\mathrm{CD} 4{ }^{+} \mathrm{CD} 62 \mathrm{~L}^{+} \mathrm{T}$ cells were activated as indicated in the polarized condition with plate-bound anti-CD3 mAbs $(1.5 \mu \mathrm{g} / \mathrm{ml}$, clone 17A2, eBioscience) and anti-CD28 mAbs (0.75 $\mu \mathrm{g} / \mathrm{ml}$, clone 37.51 , eBioscience). In some experiments, antibody or inhibitor was added at the beginning of the $\mathrm{T}$ cell cultures.

Real-time PCR. Total RNA was extracted from cultured T cells using the RNeasy Mini Kit (Qiagen), followed by cDNA synthesis with the High-Capacity cDNA Reverse Transcription Kit (Applied Biosystems). RT-PCR was conducted with
SYBR Select Master Mix (Applied Biosystems). Expression was normalized to the expression of the housekeeping gene Gapdh. Il9 forward: 5'-ATGTTGGTGACAT ACATCCTTGC-3', Il9 reverse: 5'-TGACGGTGGATCATCCTTCAG-3'; Irf1 forward: 5'-AGGCATCCTTGTTGATGTCC-3', Irf1 reverse: 5'-AATTCCAACCAAA TCCCAGG-3'; and Gapdh forward: 5'-TTGATGGCAACAATCTCCAC-3', Gapdh reverse: 5'-CGTCCCGTAGACAAAATGGT-3'.

Flow cytometry. After culture for 3 days, differentiated Th cells were restimulated for $5 \mathrm{~h}$ with TRP-1 peptide-loaded APC or phorbol myristate acetate $(50 \mathrm{ng} / \mathrm{ml}$; Sigma-Aldrich) and ionomycin (500 ng/ml; Sigma-Aldrich) in the presence of a protein transport inhibitor (GolgiPlug, BD Biosciences). Then cell surface markers were stained in flow cytometry staining buffer for $30 \mathrm{~min}$ on ice after Fc blocking, followed by staining for intracellular cytokines with the BD Fixation/Permeabilization Solution Kit. The results were analyzed using a fluorescence-activated cell sorter (FACS) Fortessa flow cytometer. aCD4 (clone RM4-4, 1:100), aIL-9 (clone RM9A4, 1:100), aIL-4 (clone 11B11, 1:100), and aIL-10 (clone JES5-16E3, 1:100) were from BioLegend; aIL-13 (clone eBio13A, 1:100) from ThermoFisher; ap-Smad-3 (clone O72-670, 1:50) from BD; and ap-Smad-5 (clone 41D10, 1:800) from CST.

Enzyme-linked immunosorbent assay. After $72 \mathrm{~h}$ of polarization, cell culture supernatants were tested by ELISA for mouse IL-9 (ThermoFisher) or IL-10 (ThermoFisher) or IL-5 (ThermoFisher) according to the manufacturer's protocol.

RNA interference of RelA. siRNA targeting RelA and non-specific siRNA were purchased from ThermoFisher and transfected into $\mathrm{T}$ cells by Lipofectamine RNAiMAX Transfection Reagent (ThermoFisher) ${ }^{38}$.

Luciferase reporter assay. Mouse $I l 9$ promoter (from -895 to +5 ) was subcloned into pGL4.10 basic vector (Promega). 293T cells were transiently transfected $24 \mathrm{~h}$ with reporter plasmids along with expression vectors ${ }^{15}$ for RelA, RelB, c-Rel, p50, and p52 or control vector by Lipofectamine 2000 (Invitrogen). Luciferase was measured with the Dual-Luciferase Reporter Assay System according to the manufacturer's instructions (Promega).

ChIP assay. SimpleChIP Plus Enzymatic Chromatin IP kits (Cell Signaling Technology) were used for ChIP assays according to the manufacturer's protocol. For the ChIPn, anti-RelA and isotype-matched control antibody were purchased from Cell Signaling and used at a 1:50 dilution. The DNAs were analyzed by RTPCR with the following primer set surrounding the RelA-binding site at the Il9 promoter region. ChIP primers: Forward: 5'-GCACTGGGTATCAGTTTGATG-3', Reverse: 5'-CTCAGTCTACCAGCATCTTCC-3'. Values were subtracted from the amount of IgG control and were normalized to the corresponding input control.

Fractionation of the lung. C57BL/6 WT mice or Illr KO mice were challenged with $1 \times 10^{5}$ B16-OVA melanoma cells. Mice were intraperitoneally (i.p.) given control IgG or aCD4-depletion mAbs (clone GK1.5, $200 \mu \mathrm{g} /$ mice) on days 8 and 11 and then sacrificed on day 14. Lung tumor tissues were digested with $1 \mathrm{mg} / \mathrm{ml}$ of collagenase D (Roche) for $30 \mathrm{~min}$ at $37^{\circ} \mathrm{C}$ and then with $0.01 \mathrm{mM}$ EDTA (SigmaAldrich) for $5 \mathrm{~min}$, to prevent aggregates. The cells were collected using Ficoll 
(GE Healthcare) density gradient centrifugation and the middle section of the gradient was enriched for leukocytes.

In vitro cytotoxicity assay. $\mathrm{B} 16$ target cells for TRP- $1 \mathrm{CD} 4^{+} \mathrm{T}$ cells were labeled with $5 \mu \mathrm{M}$ carboxyfluorescein succinimidyl ester (CFSE), whereas MC38 nontarget cells were labeled with $0.25 \mu \mathrm{M}$ CFSE as the control. B16 target (CFSEhigh) or MC38 nontarget (CFSE ${ }^{\text {low }}$ ) cells were incubated with PBS control, TRP-1specific Th2 cells, TRP-1-specific classic Th9 $9^{\mathrm{IL}-4+\text { TGF- } \beta}$ cells, or TRP-1-specific Th9 $9^{\mathrm{IL}-4+\mathrm{IL}-1 \beta}$ cells. An E:T ratio of 10:1 was used, and specific killing was determined after $48 \mathrm{~h}$ of coculture. After coculture, $\mathrm{CFSE}^{+}$cells from each target and control well were mixed and analyzed by FACS. The percentage of specific lysis was calculated as follows: $(1-R \times \mathrm{M} 2 / \mathrm{M} 1) \times 100$, where $\mathrm{M} 1=$ non-target events, $\mathrm{M} 2=$ target events, and $\mathrm{R}=\mathrm{M} 1$ in untreated group/M2 in untreated group.

Tumor model and adoptive transfer. To establish the 6-day established murine lung metastatic B16 melanoma model, mice were injected intravenously (i.v.) with $1 \times 10^{5} \mathrm{~B} 16$ tumor cells. For adoptive transfer experiments, mice were injected i.v. with $1 \times 10^{6}$ TRP-1-specific Th2, Th9 $9^{\mathrm{IL}-4+\mathrm{TGF}-\beta}$, or Th9 $9^{\mathrm{LL}-4+\mathrm{IL}-1 \beta}$ cells 6 days after tumor cell inoculation. Control IgG or $\alpha$-IL-9 were injected i.p. twice every week starting at 1 day before i.v. transfer of T cells. At days 16 or 40 after tumor inoculation, mice were sacrificed for measurement of metastatic lung foci. All lung lobes were evaluated under a tissue-dissecting microscope.

Mice were euthanized by using $\mathrm{CO}_{2}$ asphyxiation and followed by cervical dislocation if any of the following symptoms appear: (1) weight loss of $\geq 20 \%$ of baseline body weight; (2) mice display significant lameness and disability in moving. Microarray analysis. Total RNA was extracted with the RNeasy Mini Kit (Qiagen)
from 3-day cultured Th1, Th2, classic Th9 $9^{\mathrm{IL}-4+\mathrm{TGF}-\beta}$, Th9 $9^{\mathrm{IL}-4+\mathrm{IL}-1 \beta}$, and Th9 $9^{\mathrm{LL}-4}$ + TGF- $\beta+$ IL- $1 \beta$ cells. RNA samples were sent to the Case Western Reserve University Genomic Core for quality evaluation using an Agilent Bioanalyzer. Samples with intact $18 \mathrm{~S}$ and $28 \mathrm{~S}$ ribosomal RNA bands with RNA integrity number $>8.5$ were processed for microarray analysis performed with a Mouse Gene 2.0 ST Kit at the Case Western Reserve University Genomic Core. GSEA was implemented using newly generated gene expression profiles of the five cell types and downloaded GSEA software (gsea-v3.0, http://software.broadinstitute.org/gsea/downloads.jsp). $P$ values were calculated with Kolmogorov-Smirnov test (threshold $=0.01$ ). The false discovery rate, $q$ value, is the estimated probability that a gene set with a given NES represents a false positive finding. The threshold for $q$ value in GSEA is 0.25 . Gene sets for the mature effector were derived from a publicly available study of the genes differentially expressed by more than two-fold in quaternary versus primary cells ${ }^{39}$. Venn diagram analysis based on Cut-tree algorithm. To compare our
Th9 $9^{\mathrm{IL}-4+\mathrm{IL}-1 \beta}$ cells with other cells, including known Th9 (Th9 $9^{\mathrm{IL}-4+\mathrm{TGF}-\beta)}$, and another Th9 cell induced by three molecules (Th9 $\left.9^{\mathrm{IL}-4+\mathrm{TGF}-\beta+\mathrm{IL}-1 \beta}\right)$, and Th1 and Th2 cells, we utilized un-supervised hierarchical clustering 39 to cluster all genes in the microarray data into 10 clusters. Clusters $1-10$ were identified by Cut-tree algorithm using the same distance method of average as hierarchical clustering ${ }^{39}$.

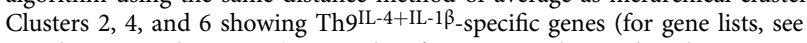
Supplementary data $1,2,3$ ) were taken for commonality analysis by Venn graph ${ }^{21}$. The overlaps among the three cell types Th2, classic Th9 $9^{\mathrm{IL}-4+\mathrm{TGF}-\beta}$, and Th9 $9^{\mathrm{IL}-4}$ $+\mathrm{IL}-1 \beta$ were analyzed by Venn diagram. The threshold for the upregulated genes for clusters 2,4 , and 6 is $z$-score $=0.9$, where $z$-score is the scaled value of each gene across the 5 cell types. Hierarchical clustering was analyzed by complexheatmap using $\mathrm{R}$ and Venn diagram analysis was implemented by VennDiagram in $\mathrm{R}$ (https://www.r-project.org/).

Statistical analyses. For statistical analysis, Student's $t$ test was used. A $P$ value $<0.05$ was considered statistically significant. Results are presented as mean \pm standard deviations $(\mathrm{SD})$.

Reporting Summary. Further information on experimental design is available in the Nature Research Reporting Summary linked to this article.

\section{Data availability}

The microarray data reported in this paper are deposited in the Gene Expression Omnibus (GEO) database under the accession number GSE123624. The data for the bar charts and graphs are available in the Source Data file. The other data that support the findings of this study are available from the corresponding author upon reasonable request.

Received: 25 September 2018 Accepted: 28 February 2019 Published online: 26 March 2019

\section{References}

1. Dardalhon, V. et al. IL-4 inhibits TGF- $\beta$-induced Foxp $3+$ T cells and, together with TGF- $\beta$, generates IL-9+IL-10+Foxp3- effector T cells. Nat. Immunol. 9, 1347-1355 (2008)

2. Veldhoen, $M$. et al. Transforming growth factor- $\beta$ 'reprograms' the differentiation of T helper 2 cells and promotes an interleukin 9-producing subset. Nat. Immunol. 9, 1341-1346 (2008).

3. Chang, H. C. et al. The transcription factor PU.1 is required for the development of IL-9-producing T cells and allergic inflammation. Nat. Immunol. 11, 527-534 (2010).

4. Staudt, V. et al. Interferon-regulatory factor 4 is essential for the developmental program of T helper 9 cells. Immunity 33, 192-202 (2010).

5. Goswami, R. et al. STAT6-dependent regulation of Th9 development. J. Immunol. 188, 968-975 (2012).

6. Jabeen, R. et al. Th9 cell development requires a BATF-regulated transcriptional network. J. Clin. Invest. 123, 4641-4653 (2013).

7. Bi, E. et al. Foxol and Foxp1 play opposing roles in regulating the differentiation and antitumor activity of TH9 cells programmed by IL-7. Sci. Signal. 10, eaak9741 (2017).

8. Wang, Y. et al. Histone deacetylase SIRT1 negatively regulates the differentiation of interleukin-9-producing CD4+T cells. Immunity 44, 1337-1349 (2016).

9. Liao, W. et al. Opposing actions of IL-2 and IL-21 on Th9 differentiation correlate with their differential regulation of BCL6 expression. Proc. Natl Acad. Sci. 111, 3508-3513 (2014).

10. Kaplan, M. H., Hufford, M. M. \& Olson, M. R. The development and in vivo function of T helper 9 cells. Nat. Rev. Immunol. 15, 295-307 (2015).

11. Cheng, G. et al. Anti-interleukin-9 antibody treatment inhibits airway inflammation and hyperreactivity in mouse asthma model. Am. J. Respir. Crit. Care Med. 166, 409-416 (2002).

12. Jager, A., Dardalhon, V., Sobel, R. A., Bettelli, E. \& Kuchroo, V. K. Th1, Th17, and Th9 effector cells induce experimental autoimmune encephalomyelitis with different pathological phenotypes. J. Immunol. 183, 7169-7177 (2009).

13. Lu, Y. et al. Th9 cells promote antitumor immune responses in vivo. J. Clin. Invest. 122, 4160-4171 (2012).

14. Nonomura, Y. et al. Peripheral blood Th9 cells are a possible pharmacodynamic biomarker of nivolumab treatment efficacy in metastatic melanoma patients. Oncoimmunology 5, e1248327 (2016).

15. Lu, Y. et al. Th9 cells represent a unique subset of CD4+ T cells endowed with the ability to eradicate advanced tumors. Cancer Cell 33, 1048-1060.e7 (2018).

16. Schmitt, E. et al. IL-9 production of naive CD4+T cells depends on IL-2, is synergistically enhanced by a combination of TGF-beta and IL-4, and is inhibited by IFN-gamma. J. Immunol. 153, 3989-3996 (1994).

17. Jones, C. P. et al. and TGF- $\beta$ promote T H9 cell-mediated pulmonary allergic pathology. J. Allergy Clin. Immunol. 129, 1000-1010.e3 (2012).

18. Reynolds, L. A. \& Maizels, R. M. Cutting edge: in the absence of TGF- $\beta$ signaling in T cells, fewer CD103+ regulatory $\mathrm{T}$ cells develop, but exuberant IFN- $\gamma$ production renders mice more susceptible to helminth infection. J. Immunol. 189, 1113-1117 (2012).

19. Horka, H. et al. The tick salivary protein sialostatin $\mathrm{L}$ inhibits the Th9-derived production of the asthma-promoting cytokine IL-9 and is effective in the prevention of experimental asthma. J. Immunol. 188, 2669-2676 (2012).

20. Végran, F. et al. The transcription factor IRF1 dictates the IL-21-dependent anticancer functions of T H9 cells. Nat. Immunol. 15, 758-766 (2014).

21. Chen, H. \& Boutros, P. C. VennDiagram: A package for the generation of highly-customizable Venn and Euler diagrams in R. BMC Bioinformatics 12, 35 (2011).

22. Lukens, J. R., Barr, M. J., Chaplin, D. D., Chi, H. \& Kanneganti, T.-D. Inflammasome-derived IL-1 regulates the production of GM-CSF by CD4+ $\mathrm{T}$ cells and T cells. J. Immunol. 188, 3107-3115 (2012).

23. El-Behi, M. et al. The encephalitogenicity of TH 17 cells is dependent on IL-1- and IL-23-induced production of the cytokine GM-CSF. Nat. Immunol. 12, 568-575 (2011).

24. Regateiro, F. S. et al. Generation of anti-inflammatory adenosine byleukocytes is regulated by TGF- $\beta$. Eur. J. Immunol. 41, 2955-2965 (2011).

25 . Ryzhov, S. V. et al. Role of TGF- $\beta$ signaling in generation of $\mathrm{CD} 39^{+} \mathrm{CD}^{+} 3^{+}$ myeloid cells in tumors. J. Immunol. 193, 3155-3164 (2014).

26. Park, J. et al. Murine Th9 cells promote the survival of myeloid dendritic cells in cancer immunotherapy. Cancer Immunol. Immunother. 63, 835-845 (2014).

27. Lu, Y. \& Yi, Q. Utilizing T9 cells as a novel therapeutic strategy for malignancies. Oncoimmunology 2, e23084 (2013).

28. Sullivan, B. M., Juedes, A., Szabo, S. J., von Herrath, M. \& Glimcher, L. H. Antigen-driven effector CD8 T cell function regulated by T-bet. Proc. Natl Acad. Sci. USA 100, 15818-15823 (2003).

29. Knox, J. J., Cosma, G. L., Betts, M. R. \& McLane, L. M. Characterization of T-bet and Eomes in peripheral human immune cells. Front. Immunol. 5, 217 (2014). 
30. Pearce, E. L. et al. Control of effector CD8+T cell function by the transcription factor eomesodermin. Science 302, 1041-1043 (2003).

31. Wong, M. T. et al. Regulation of human Th9 differentiation by type I interferons and IL-21. Immunol. Cell Biol. 88, 624-631 (2010).

32. Angkasekwinai, P., Chang, S. H., Thapa, M., Watarai, H. \& Dong, C. Regulation of IL-9 expression by IL-25 signaling. Nat. Immunol. 11, 250-256 (2010).

33. Xiao, X. et al. OX40 signaling favors the induction of TH9 cells and airway inflammation. Nat. Immunol. 13, 981-990 (2012).

34. Xiao, X. et al. GITR subverts Foxp3+Tregs to boost Th9 immunity through regulation of histone acetylation. Nat. Commun. 6, 8266 (2015).

35. Kim, I. K. et al. Glucocorticoid-induced tumor necrosis factor receptor-related protein co-stimulation facilitates tumor regression by inducing IL-9producing helper T cells. Nat. Med. 21, 1010-1017 (2015).

36. Nakatsukasa, H. et al. The DNA-binding inhibitor Id3 regulates IL-9 production in CD4+T cells. Nat. Immunol. 16, 1077-1084 (2015).

37. Hayden, M. S. \& Ghosh, S. Regulation of NF-kB by TNF family cytokines. Semin. Immunol. 26, 253-266 (2014).

38. Ma, X. et al. Cholesterol negatively regulates IL-9-producing $\mathrm{CD} 8^{+} \mathrm{T}$ cell differentiation and antitumor activity. J. Exp. Med. 215, 1555-1569 (2018).

39. Gu, Z., Eils, R. \& Schlesner, M. Complex heatmaps reveal patterns and correlations in multidimensional genomic data. Bioinformatics 32, 2847-2849 (2016).

\section{Acknowledgements}

This work was supported by grants from the National Cancer Institute (K99CA190910 and 4R00CA190910-03), the Elsa u. Pardee Foundation Award 2019, and Wake Forest Start-up funds. We also acknowledge the editorial assistance of Karen Klein, MA, in the Wake Forest Clinical and Translational Science Institute (UL1 TR001420; PI: McClain). Research reported in this publication was also supported by the National Center for Advancing Translational Sciences of the National Institutes of Health under Award Number UL1TR001420 (CTSI Pilot Grant Award 2018, CTSI Pilot Grant Award 2019, and CTSI Ignition Fund Pilot award). This study was also supported by the National Cancer Institute's Cancer Center Support Grant award number P30CA012197 issued to the Wake Forest Baptist Comprehensive Cancer Center. The content is solely the responsibility of the authors and does not necessarily represent the official views of the National Cancer Institute.

\section{Author contributions}

Y.L. initiated this study. G.X. and Y.L. designed the experiments and wrote the paper. G.X. performed most of the experiments and statistical analyses. G.J. helped with data analysis and provided critical suggestions. J.F. helped with animal studies.

\section{Additional information}

Supplementary Information accompanies this paper at https://doi.org/10.1038/s41467019-09401-9.

Competing interests: The authors declare no competing interests.

Reprints and permission information is available online at http://npg.nature.com/ reprintsandpermissions/

Journal peer review information: Nature Communications thanks Tobias Bopp and the other anonymous reviewer(s) for their contribution to the peer review of this work.

Publisher's note: Springer Nature remains neutral with regard to jurisdictional claims in published maps and institutional affiliations.

(c) (i) Open Access This article is licensed under a Creative Commons Attribution 4.0 International License, which permits use, sharing, adaptation, distribution and reproduction in any medium or format, as long as you give appropriate credit to the original author(s) and the source, provide a link to the Creative Commons license, and indicate if changes were made. The images or other third party material in this article are included in the article's Creative Commons license, unless indicated otherwise in a credit line to the material. If material is not included in the article's Creative Commons license and your intended use is not permitted by statutory regulation or exceeds the permitted use, you will need to obtain permission directly from the copyright holder. To view a copy of this license, visit http://creativecommons.org/ licenses/by/4.0/.

(C) The Author(s) 2019 